\title{
Implications of New Keynesian Theory for Benchmarking of Monetary Efficiency
}

\author{
Oghenovo A. Obrimah \\ Department of Economics, Banking, and Finance, Babcock University, Nigeria \\ Tel: 234-0903-920-2317. E-mail: oobrimah@gmail.com \\ RH Smith School of Business, University of Maryland, College Park, USA
}

Received: December 8, 2015

Accepted: August 14, 2016 Published: August 30, 2016

doi:10.5296/ijrd.v3i2.9959

URL: http://dx.doi.org/10.5296/ijrd.v3i2.9959

\begin{abstract}
Relative to free floating exchange rate regimes, I find the adoption of a hybrid exchange rate regime induces alternate monetary policy responses within the context of new Keynesian theory. Specifically, while the efficiency with which an economy is managed can be derived from comparisons of effects of inflation or balance of payments on exchange rates within a cross-section of countries that run free floating exchange rate regimes, this is not the case within a cross-section of countries that operate hybrid exchange rate regimes. In countries that operate hybrid exchange rate regimes, the efficiency with which an economy is managed is derived from comparisons of the effects of exchange rates on inflation or balance of payments situations. In so far as measurement of economic distortions are concerned, while relations between deposit or lending interest rates and inflows of Foreign Direct Investment (FDI) into countries with hybrid exchange rate regimes yield insights into the extent to which inflows of foreign capital induce distortionary effects on price equilibriums, these relations do not yield similar insights within a cross-section of countries that run free floating exchange rate regimes. These findings, generated within the context of new Keynesian theory, identify theoretically appropriate differences in benchmarking of economic efficiency conditional on differences in exchange rate regimes.
\end{abstract}

Keywords: Monetary Policy, Efficiency, Foreign Direct Investment, Equilibriums, New Keynesian Theory, Investments, Financing, Inflation, Exchange Rates, Balance of Payments

JEL: E12, E52

\section{Introduction}

The basic formulation of Keynesian theory results in the IS-LM-AS curves, which respectively, describe relations between interest rates and output, income and interest rates, 
and relations between prices and output. Within the context of these formulations the unknowns within the economic system are output, interest rates, and the price level. The addition of the AS curve to the IS-LM curve is predicated on the standard Keynesian assumption of fixed prices. The positive relation between prices and output predicted by the AS curve also is predicated on the assumption of perfect competition and price rigidities that is, a market within which all agents are price takers (see for example, Barro and Grossman, 1971).

In more recent extensions of Keynesian theory, the assumption of perfect competition has been relaxed, such that each firm within an economy faces a downward sloping demand curve, or equivalently, markets characterized by imperfect competition. This results in a situation where prices are more likely to decrease with output due to competitive effects between firms within an industry. Coupled with the relaxation of the assumption that prices do not adjust within the context of the IS-LM curve, these extensions to Keynesian theory render the AS curve unnecessary since price effects can be motivated within the context of the IS-LM curves. In Ball, Mankiw, and Romer (1988) for instance, nominal shocks have little effect on output when prices are able to adjust frequently subsequent to the arrival of a nominal shock. Given frequent price adjustments result in higher levels of inflation, these extensions to Keynesian theory relax the assumption of fixity in inflation that is implicit in basic formulations of Keynesian theory.

In so far as interactions between the IS and LM curves are concerned, since the LM curve introduces income shocks that affect interest rates, while the IS curve introduces interest rate shocks that affect output, it seems logical to focus on the effects of income shocks on interest rates and the resulting effects on output. Within this context, the extent to which interest rates adjust to changes in income in order to maintain savings rates has implications for output levels and accompanying price levels. In the presence of "sticky prices" (an assumption of Keynesian theory that remains a key component of New Keynesian theory), however, interest rates may not adjust to levels that restore preceding equilibriums. In this sense, Keynesian theory revolves around the disequilibrium effects of nominal shocks and policy responses that attempt to restore preceding equilibriums or target new equilibriums. Given equilibrium is restored whenever interest rate adjustments maintain equality relations between planned investments and savings, disequilibrium revolves around non-equality between planned investments and savings. The assumption of disequilibriums implies demand is not unit elastic (demand does not adjust in such a way that output levels are kept constant), and allows for the presence of supply shocks. Evidence of demand elasticities not equal to one are provided in Mankiw and Summers (1986).

In this note, I discuss differences in the implications of New Keynesian theory for benchmarking of monetary efficiency in countries that do not run free floating exchange rate regimes. Specifically, I focus on how differences in demand (disequilibrium) effects induced by nominal income shocks influence questions of interest (equivalently, theoretically appropriate measurements of monetary efficiency) or monetary policy responses conditional on the choice of exchange rate regime. In assessing the differential impacts of income shocks, I abstract away from the sources of income shocks; that is do not delve into effects of 
nominal rigidities in wages on resulting disequilibrium states. For studies of the effects of nominal rigidities in wages on disequilibrium states, see for example, Bailey (1974), Azariadis (1975), and Hall (1975).

The assumption of disequilibrium consequent on an income shock results in three potential disequilibrium states. If interest rate adjustments consequent on an income shock result in an increase in savings rates, prices go down. Depending on relations between the increase in income and the change in savings rates, output either decreases or increases. This leads to two disequilibrium states within which prices are lower, while output either is higher or lower than in the preceding equilibrium state.

If interest rate adjustments consequent on income shocks do not induce consumers to maintain savings rates, this can result in a deficit of capital relative to planned investment. In the presence of an increase in income and a decrease in savings rates, investors have an incentive to increase output levels. If these adjustments result in a deficit of capital, this results in an increase in the cost of capital and an increase in prices. This is the scenario depicted by the AS curve, that is, a positive relation between output and prices. This positive relation between prices and output also is an empirical artifact of classical models, such as that of Lucas (1972). As noted in Lucas (1972), however, the positive relation between output and prices is a resulting empirical relation, as opposed to a theoretically motivated relation, and as such does not have any implications for inflation levels.

Within the context of New Keynesian theory and relative to the incidence of nominal shocks, prices and inflation are outcome variables, the relative adjustments of which depend on the extent to which markets are imperfect and the extent to which prices are sticky (see for example, Akerlof \& Yellen, 1985; Ball \& Romer, 1987; Blanchard \& Kiyotaki, 1987; Gordon, 1981; Mankiw, 1985; Schultze, 1985). Mankiw, Akerlof, and Yellen find the macroeconomic effects of nominal rigidities can be much greater than the costs. Blanchard and Kiyotaki find nominal rigidities yield externalities for aggregate demand with consequent effects on output. Explanations for protractions in price rigidities include the inertia effects of staggered price setting within the context of imperfect competition (see for example, Blanchard, 1986; and Taylor, 1979, 1980); asymmetric effects of demand shocks (see for example, Kuran, 1983); and imperfect competition (see for example, Arrow, 1959) among other theories.

Since countries that have inflation targets seek to achieve a certain level of inflation, inflation cannot be regarded as an exogenous outcome variable within the context of New Keynesian theory. This renders applications of New Keynesian theory difficult within the context of free floating exchange rate regimes. In countries that run hybrid exchange rate regimes, however, inflation and prices can be treated as outcome variables. These trade-offs have been enunciated in the principle of the "trilemma", which predicts countries cannot simultaneously pursue independent monetary and exchange rate policies (see for example, Bleaney, Lee, \& Lloyd, 2012; Cohen, 1993; Tavlas, 2003; and McCallum and Nelson (1991). Given ambiguities in relations between investments and inflation (see for example, Ball \& Sheridan, 2005; Bernanke et al., 1999; Epstein \& Yeldan, 2008; Pollin \& Zhu, 2006), a priori an 
increase in inflation cannot be said to be unequivocally detrimental to investments, economic growth, or economic development.

My findings demonstrate that attempts at benchmarking of monetary efficiency must recognize there exist subtle but important differences in policy variables and outcomes between countries that operate free floating or hybrid exchange rate regimes. In countries that operate hybrid exchange rate regimes, interactions between exchange rates, interest rates, and income induce changes in inflation, balance of payments situations, and productivity. In countries that run free floating exchange rate regimes, the presence of hard inflation targets as monetary policy variables results in interactions between inflation, interest rates, income, and balance of payments situations that induce changes in productivity and exchange rates. In this second set of countries, inflation is an input variable, balance of payments situations are intermediate outcome variables, while both productivity and exchange rates are outcome variables. These differences between free floating and hybrid exchange rate regimes have implications for cross-country comparisons of monetary equilibriums. Specifically, while it is differences in relations between balance of payments situations and exchange rates or interest rates that are measures of monetary efficiency within the cross-section of countries that operate hybrid exchange rate regimes, it is differences in relations between exchange rates and balance of payments situations that are measures of monetary efficiency within the cross-section of countries that operate free floating exchange rate regimes. Also, while inflows of Foreign Direct Investment (FDI) into countries that operate hybrid exchange rate regimes can distort existing price equilibriums within the banking and real sectors, such distortionary effects are not characteristic of countries that operate free floating exchange rate regimes.

Ball, Mankiw, and Romer (1988) develop a model within which price changes are both endogenous and sticky subsequent to the incidence of nominal shocks. This results in the prediction that the real effects of nominal shocks are smaller when average inflation is higher. This is equivalent to stating the real effects of nominal shocks are smaller when price adjustments to the incidence of nominal shocks are more frequent. This relation between the output effects of nominal shocks and average inflation is similar to the prediction of a steep Phillips curve for the relation between output and the variance of aggregate demand in Lucas (1972). Consistent with my finding that the implications of New Keynesian theory require relatively "unplanned economies", Ball, Mankiw, and Romer restrict sample countries utilized in empirical tests of their model's predictions to relatively unplanned countries.

The rest of the paper is structured as follows. I discuss implications of differences in exchange rate regimes for theoretically appropriate monetary policy responses or measurements of monetary efficiency within the context of New Keynesian theory in Section II. Section III concludes.

\section{New Keynesian theory: Differences between Hybrid and Free Floating Rate Regimes}

The Taylor Equation for an open economy provides a rich context for exploring the implications of New Keynesian theory. Consistent with representations in Canale (2011) and 
Ball, Mankiw, and Romer (1988, pg. 51), the Taylor Equation or representation of New Keynesian theory can be specified as:

$$
i_{-} t=i^{\wedge} T+\alpha\left(\pi^{\wedge} t-\pi^{\wedge} T\right)+\beta\left(y^{\wedge} t-y^{\wedge} T\right)+\gamma\left(e^{\wedge} t-e^{\wedge} T\right)
$$

Where $\mathrm{i} \_\mathrm{t}$ are periodic interest rates, $\pi^{\wedge} \mathrm{t}$ are periodic inflation, $\mathrm{y}^{\wedge} \mathrm{t}$ are periodic income, and $\mathrm{e}^{\wedge} \mathrm{t}$ are periodic exchange rates. $\mathrm{i}^{\wedge} \mathrm{T}, \pi^{\wedge} \mathrm{T}, \mathrm{y}^{\wedge} \mathrm{T}$, and $\mathrm{e}^{\wedge} \mathrm{T}$ are, respectively, equilibrium levels of interest rates, inflation, income, and exchange rates.

In order to impose some structure on the discussion, I assume the principle of the trilemma holds; that is, countries that have hard inflation targets (free floating exchange rate regimes) do not simultaneously and independently manage exchange rates. The trilemma principle also implies countries that run hybrid exchange rate regimes do not simultaneously and independently manage inflation with hard inflation targets.

Suppose income, y, increases while an economy is in equilibrium, with equilibrium implying achievement of target inflation levels (free float regimes) or currency valuations (hybrid regimes). Keynesian theory predicts an increase in interest rates in order to maintain savings rates. Since extensions to Keynesian theory (New Keynesian theory) allow for changes in prices, depending on adjustments to savings rates and the effects of these adjustments on relations between planned investments and savings, the increase in interest rates can result in a decrease or increase in prices and inflation levels.

Suppose an increase in income results in an increase in prices and inflation. In countries where Central Banks set hard inflation targets, the increase in inflation results in policies targeted at reining in inflation. In countries where Central Banks primarily manage exchange rates - countries that operate hybrid exchange rate regimes, however, the increase in inflation results in policy responses only if it simultaneously induces depreciation pressure on the value of the domestic currency; that is, only if it has real effects on either of investments, savings, or both. This is the first important dichotomy between countries that run free floating or hybrid exchange rate regimes, which is:

Remark 1: While an increase in price levels or inflation results in a policy response within countries that set inflation targets, such changes necessitate policy responses in countries that run hybrid exchange rate regimes only if the increase in price levels or inflation induces disequilibrium between savings and planned investments, resulting in currency depreciation pressure.

An immediate and important implication of Remark 1 is that hybrid exchange rate regimes implicitly allow their economies to attempt to arrive at new equilibrium levels consequent on the incidence of nominal shocks. In these countries, Central Banks step in to alter equilibriums only when it is possible to move the economy to a better equilibrium. This better equilibrium can be the preceding equilibrium or a totally new equilibrium. In countries that run free floating exchange rate regimes, however, the central planner responds to the nominal shock either by attempting to recover the preceding equilibrium or via an adjustment in inflation targets. These two sets of responses are identical only if the determination of better 
equilibrium states is dependent on the negative effects of disequilibrium on investments or savings.

Remark 2: Responses to nominal income shocks in countries that run hybrid or free floating exchange rate regimes are theoretically identical only if free floating exchange rate regimes adopt "soft" inflation targets, with the determination of better equilibrium states dependent on the negative effects of disequilibrium on investments or savings.

\subsection{Interest Rate Adjustments Result in a Decrease in Savings Rates}

If interest rate adjustments do not result in the maintenance of the equality relation between planned investment and savings, the cost of production increases, resulting in an increase in prices. Since inability to maintain savings rates implies an increase in aggregate consumption (incomes have risen in aggregate, while savings have decreased), output also increases to satisfy demand. In aggregate then, inability to maintain savings rates consequent on a nominal income shock results in an increase in prices and output.

The assumption of equilibrium prior to the incidence of a nominal shock to income results in a situation where countries that manage inflation either revise inflation targets or seek to return to the initial equilibrium state. Regardless of the strategic decision, however, inflation can only be stabilized if the equality relation between planned investment and savings is realized. If countries that run free floating exchange rate regimes attempt to manage inflation by decreasing money supply, this results in an increase in the cost of capital and as a result is ineffective at achieving a new equilibrium state with steady or stable inflation. The fact that a decrease in income is contrary to risk preferences-risk aversion, risk seeking, or loss aversion preferences-implies a negative shock to income is not desirable and as such is a potential strategy only if it is necessary to avert economic crises. This results in a situation where the cheapest route to restoring equilibrium is the inducement of savings rates that enable the equality relation between planned investment and savings; hence the adoption of interest rates as monetary policy variables.

Since countries that run hybrid exchange rate regimes do not set hard inflation targets, the increase in prices and output necessitates a policy response only when it results in a decrease in exports or a significant increase in imports that affects the viability of domestic production. (Note 1)

In either case (increase in imports or decrease in exports), depreciation of the domestic currency can enable restoration of preceding equilibrium levels. Equilibrium levels also can be restored by inducing an increase in savings rates that enables the equality relation between planned investments and savings. If Foreign Direct Investment (FDI) is substituted for an increase in savings via currency devaluation, savings interest rates are depressed, lending rates have potential to be inefficient (too high or too low), and distortions to equilibrium can be inefficient. Since the price of foreign currency always is determined by market forces in countries that operate free floats, theoretically it is unlikely that FDI can induce inefficient distortions to equilibrium within such countries. 
The discussion leads to the following differences between countries that run free floating or hybrid exchange rate regimes

Remark 3: In countries that run free floating exchange rate regimes, an income shock that results in an increase in prices and output results in adjustments to equilibrium inflation levels or attempts at reining in inflation. In countries that run hybrid exchange rate regimes, an income shock that results in an increase in prices and output can necessitate adjustments to the value of the domestic currency only if the increase in prices and output is detrimental to exports or induces over reliance on imports.

Since by assumption, interest rate adjustments are in of themselves insufficient to restore equilibrium, equilibrium is induced within either of free floating or hybrid exchange rate regimes via a decrease in money supply that induces a decrease in planned investments. In countries that operate free floating exchange rate regimes, the domestic money market can be segmented from the international money market. Given similar segmentation is not feasible within countries that operate hybrid exchange rate regimes, while a decrease in money supply is consistent with attempts at reining in inflation within free floating exchange rate regimes and is unlikely to induce any new risks, a decrease in money supply simultaneously induces an increase in currency valuations within hybrid exchange rate regimes. Since an increase in currency valuations can result in a decrease to exports or increase in imports, or both, a money supply strategy creates new risks within hybrid exchange rate regimes. In such situations, doing nothing can be more efficient than a decrease in money supply within hybrid exchange rate regimes.

Within the context of cross-country studies, New Keynesian theory implies alterations in equilibrium levels can be captured by examining the effects of changes in inflation or resulting balance of payments situations on exchange rates using a cross-section of countries that run free floating exchange rate regimes. That is, a country that operates a free floating exchange rate regime can measure the efficiency of economic decisions by comparing the effects of inflation on balance of payments situations or exchange rates, or via a comparison of the effects of balance of payments situations on exchange rates.

\subsection{Interest Rate Adjustments Result in an Increase in Savings Rates}

If interest rate adjustments result in an increase in savings rates, such that savings are greater than planned investments, the cost of capital goes down, resulting in lower prices. Since income has increased, savings rates can increase yet allow for an increase in or the maintenance of unit consumption levels that obtained in the preceding equilibrium. In this scenario, demand is maintained or higher, while prices decrease, resulting in a situation where new output levels (price multiplied by unit consumption) may be lower than output levels that obtained in the initial equilibrium. This implies a decrease in output is not necessarily indicative of the absence of economic growth or development.

\subsubsection{Decrease in Prices and Output}

If both prices and output decrease consequent on the increase in savings rates, stimulation of investments is desirable if the associated increase in prices and output has potential to 
improve social welfare. In the banking literature for instance, holding lending rates constant, this increase in social welfare can be induced by increased competition for deposits that results in higher deposit rates for bank customers (see for example, Boyd and De Nicolo, 2005). Since banks' lending volumes increase, the decrease in gross margins that is beneficial for social welfare does not imply a decrease in aggregate profits. If additional interest rate adjustments are utilized, both planned investments and savings increase, resulting in a new equilibrium level within which planned investments can be equal to savings. Since an increase in savings implies a decrease in consumption, however, new investments have to be targeted at the exports market in order to avoid either of deflation or inflation.

Countries that run hybrid exchange rate regimes can take advantage of lower price levels to pursue an exchange rate policy that lowers currency values in order to stimulate the development of an export market. Within the context of a decrease in prices and output then, we can motivate interactions between exchange rates, inflation, and output in countries that run hybrid exchange rate regimes that have consequences for these countries' balance of payments.

In countries that run free floating exchange rate regimes, higher levels of investments and output can be achieved via an increase in interest rates that restores preceding inflation levels. Given new investments have to be initially targeted at the export sector in order to avoid deflation induced by an increase in savings, however, this results in interactions between interest rates and the balance of payments, with resulting effects on the value of the currency.

If a country that runs a free floating exchange rate regime chooses not to make any additional adjustments to interest rates, investments increase if foreign capital for producing goods or services can be attracted from foreign countries. This exposes the country to foreign nominal shocks, and as such can only be undertaken by countries within which domestic consumption is significantly larger than planned investments in the export market.

Remark 4: In countries that run hybrid exchange rate regimes, an interest rate response to a decrease in prices and output is never optimal outside of considerations of the viability of current currency valuations for an increase in exports. This implies an increase in interest rates is optimal only when currency values are already at levels that are beneficial for exports. If currency values are not at levels that are beneficial for exports, hybrid exchange rate regimes respond to a decrease in prices and output by adopting an exchange rate policy that focuses on currency depreciation. In this scenario, interactions between exchange rates and interest rates have implications for inflation, output, and balance of payments realizations.

Remark 5: In countries that run free floating exchange rate regimes, a decrease in prices and output results in interactions between interest rates and the balance of payments with resulting implications for exchange rates. In this scenario, balance of payments realizations are intermediate realizations that ultimately determine exchange rate outcomes.

\subsubsection{Decrease in Prices Coupled with Increase in Output}

Since an increase in savings rates occurs consequent on a nominal shock to income, it is possible for savings rates to increase in such a way that output levels are maintained or 
increase. In situations where output levels are maintained or increase in spite of an increase in savings rates (due to an increase in demand), interest rate adjustments that induce additional savings result in a relatively worse equilibrium. The equilibrium that results from an increase in interest rates is worse because it attempts to replicate an economy within which savings are greater than planned investments (the inducement of more savings eventually results in a decrease in consumption and as a result a decrease in planned investments).

If there is interest in increasing the level of investments, the focus has to be on the development of an export sector as in the preceding case (Section 2.2.1). This is the case because since output has adjusted optimally in response to the income shock, any additional increase in output targeted at domestic consumption increases the disequilibrium between planned investments and savings. In order to mitigate distortions to the economy, capital for the planned investments have to come from foreign countries; that is via importation of capital. Since exchange rates are market determined in free floating exchange rate regimes, the ability to import capital depends only on risk-return trade-offs between the domestic and foreign countries. In countries that run hybrid exchange rate regimes, however, the ability to import capital depends not only on risk-return trade-offs, but also on the extent to which the implementation of the hybrid exchange rate regime appears to be systematic, appropriate, and devoid of political influence. In either scenario, capital flows from foreign countries to the domestic countries only if investors are comfortable with current and projected currency valuations and in the presence of price stability. Capital inflows will have a significant effect on currency valuations only if they become large in relation to the size of the domestic economy. Since capital inflows are targeted at the development of an export sector, this implies exchange rate effects are a function of the relative sizes of the planned increase in the export sector and the size of the domestic economy.

The risk associated with importation of capital from foreign countries is that foreign capital or foreign direct investment (FDI) can become a substitute for savings. That is, the attractiveness of the domestic economy to foreign capital keeps interest rates low such that domestic savings remain static as planned investments increase, with the shortfall increasingly satisfied using foreign capital. The undesirability of sector controls within the context of an open economy results, however, in a situation where importation of foreign capital that is merely a substitute for domestic savings is difficult to mitigate. In my opinion, the Chilean example, which involves the imposition of levies on importations of short-term capital seems a good strategy for mitigating substitutability of foreign capital for domestic savings; that is directs foreign capital outside of the short-term funds or banking system to capital investments.

In this scenario, if foreign capital or FDI is directed at non-export sectors it is more likely to become a substitute for savings, with the required increase in domestic consumption resulting in distortions to the existing equilibrium between planned investments and savings. In countries that run free floating exchange rate regimes, the appreciation of the domestic currency in relation to the foreign currencies induced by an increase in supply of FDI or foreign capital stems the flow of capital and mitigates the extent to which foreign capital becomes a substitute for domestic savings. In countries that run hybrid exchange rate regimes, 
exchange rates may not respond to inflows of foreign capital or FDI because such adjustments run counter to some of the specific objectives of exchange rate policy. These findings imply FDI or foreign capital is more likely to induce distortions to existing equilibriums in countries that operate hybrid exchange rate regimes.

Remark 6: A decrease in prices that is coupled with maintenance of or an increase in output results in an increase in social welfare and as such does not necessitate immediate policy responses to the effects of an income shock. In countries that run hybrid exchange rate regimes, however, the substitution of foreign capital or FDI for domestic savings can induce distortionary effects to existing price equilibriums, particularly within banking sectors. This implies relations between FDI and either of savings or lending interest rates are indicators of the effects of FDI on price equilibriums within countries that operate hybrid exchange rate regimes.

Remark 7: In countries that operate free floating exchange rate regimes, benchmarking of economic efficiency is implemented using relations between exchange rates and balance of payments situations, or via the parameterization of relations between balance of payments situations and inflation. In countries that operate hybrid exchange rate regimes, benchmarking of economic efficiency is implemented using relations between either of balance of payments situations or inflation and exchange rates. Relative to country-specific outcomes, differences across countries are indicators of differences in country-specific macroeconomic risk.

\subsection{The Taylor Equation}

The Taylor equation provides a structural framework for studying monetary economics within a New Keynesian economics framework. Within the context of this framework, input variables either are income shocks from activities within the private sector, shocks to investments and output that result from changes in interest rates within the private sector, or policy shocks introduced using Central Bank instruments that affect exchange rates or private sector interest rates. If country-specific or cross-country studies of monetary economics or macroeconomics are couched within the context of the Taylor equation and focus on countries that run hybrid exchange rate regimes, such studies are consistent with the implications and structure of New Keynesian economics as outlined in this note.

\section{Conclusions}

Relative to free floating exchange rate regimes, I find the adoption of a hybrid exchange rate regime induces alternate monetary policy responses within the context of New Keynesian theory. Specifically, while management of productivity in countries that run free floating exchange rate regimes does not require the inclusion of exchange rates as input variables into the production equation, the inclusion of exchange rates is implied by New Keynesian theory in management of productivity within countries that operate hybrid exchange rate regimes. Also, while the efficiency with which an economy is managed can be derived from comparisons of effects of inflation or balance of payments on exchange rates within a cross-section of countries that run free floating exchange rate regimes, this is not the case 
within a cross-section of countries that operate hybrid exchange rate regimes. In countries that operate hybrid exchange rate regimes, the efficiency with which an economy is managed is derived from comparisons of the effects of exchange rates on inflation or balance of payments situations. Implicit in these findings is a major difference in studies of monetary economics. Specifically, while my findings provide a rationale for studies that examine interactions between exchange rates and inflation in countries that operate hybrid exchange rate regimes, they provide no such rationale for similar studies in countries that operate free floating exchange rate regimes. Also, while relations between either of deposit or lending interest rates and inflows of foreign capital among countries that operate hybrid exchange rate regimes yield insights into the extent to which foreign capital has induced distortions to equilibrium prices, these relations do not yield similar insights within a cross-section of countries that operate free floating exchange rate regimes. These findings, generated within the context of New Keynesian theory, identify theoretically appropriate differences in benchmarking of economic efficiency conditional on differences in exchange rate regimes.

\section{References}

Akerlof, G. A., \& Yellen, J. L. (1985). A near-rational model of the business cycle, with wage and price inertia. Quarterly Journal of Economics, 100, 529-537.

Arrow, K. J. (1959). Toward a theory of price adjustment. In Moses Abramovitz et al. (Eds.), The Allocation of Economic Resources: Essays in Honor of Bernard Francis Haley (pp. 41-51). Stanford University Press.

Azariadis, C. (1975). Implicit contracts and underemployment equilibria. Journal of Political Economy, 83, 1183-1202.

Ball, L., \& Romer, D. (1987). Are prices too sticky? NBER Working Paper \# 217.

Ball, L., \& Sheridan, N. (2005). Does inflation targeting matter? In B. S. Bernanke \& M. Woodford (Eds.), The Inflation Targeting Debate (pp. 249-276). Chicago: University of Chicago Press.

Ball, L., Mankiw, N. G., \& Romer, D. (1988). The new keynesian economics and the output-inflation trade-off. Brookings Papers on Economic Activity I, 1-82.

Barro, R. J., \& Grossman, H. I. (1971). A general disequilibrium model of income and employment. American Economic Review, 61, 82-89.

Bernanke, B. S., Thomas, L., Mishkin, F. S., \& Posen, A. S. (1999). Inflation targeting: Lessons from the International Experience. Princeton, NJ: Princeton University Press.

Blanchard, O. J. (1986). The wage price spiral. Quarterly Journal of Economics, 101, 543-565.

Blanchard, O. J., \& Kiyotaki, N. (1987). Monopolistic competition and the effects of aggregate demand. American Economic Review, 77, 647-666. 
Bleaney, M., Lee, H., \& Lloyd, T. (2012). Testing the trilemma: exchange rate regimes, capital mobility, and monetary independence. Oxford Economic Papers (forthcoming).

Boyd, J. H., \& De Nicolo, G. (2005). The theory of bank risk taking and competition revisited. Journal of Finance, 60, 1329-1343.

Canale, R. R. (2011). Alternative strategies for monetary policy. Review of Political Economy, 23, 557-571.

Cohen, B. M. (1993). The Triad and the Unholy Trinity: Lessons for the Pacific Region. In R. Higgott, R. Leaver, \& J. Ravenhill (Eds.), Pacific Economic Relations in the 1990s: Conflict or Cooperation? Sydney, Australia: Allen and Unwin and Boulder, CO: Lynne Rienner.

Epstein, G., \& Yeldan, E. (2008). Inflation targeting, employment creation, and economic development: assessing the impacts and policy alternatives. International Review of Applied Economics, 22, 131-44.

Gordon, R. J. (1981). Output fluctuations and gradual price adjustment. Journal of Economic Literature, 19, 493-530.

Hall, M. N. (1974). Wages and unemployment under uncertain demand. Review of Economic Studies, 41, 37-50.

Hall, R. E. (1975). The rigidity of wages and the persistence of unemployment. BPEA, 2, 301-335.

Kuran, T. (1983). Asymmetric price rigidity and inflationary bias. American Economic Review, 73, 373-382.

Lucas, R. E. Jnr., (1972). Expectations and the neutrality of money. Journal of Economic Theory, 4, 103-124.

Mankiw, N. G., \& Summers, L. H. (1986). Money demand and the effects of fiscal policies. Journal of Money, Credit, and Banking, 18, 415-429.

Mankiw, N. G., (1985). Small menu costs and large business cycles: A macroeconomic model of monopoly. Quarterly Journal of Economics, 100, 529-537.

McCallum, B., \& Nelson, E. (2000). Monetary policy for an open economy: an alternative framework with optimising agents and sticky prices. Oxford Review of Economic Policy, 16, 74-91.

Pollin, R., \& Zhu, A. (2006). Inflation and Economic Growth: A cross-country non-linear analysis. Journal of Post Keynesian Economics, 4, 593-614.

Schultze, C. I. (1985), Macroeconomic efficiency and nominal wage stickiness. American Economic Review, 75, 1-15.

Tavlas, G S. (2003). The economics of exchange-rate regimes: A review essay. The World Economy, 26, 1215-46. 


\section{Macrothink}

International Journal of Regional Development ISSN 2373-9851 2016, Vol. 3, No. 2

Taylor, J. B. (1979). Staggered wage setting in macro model. American Economic Review, 69, $108-113$

Taylor, J. B. (1980). Aggregate dynamics and staggered contracts. Journal of Political Economy, 88, 1-23.

Note

Note 1. Since savings rates have decreased, currency depreciation pressure cannot be induced within the context of imbalance between savings and investments. In this scenario, the only risk is risk of currency appreciation, which will be reflected in demand for exports.

\section{Copyright Disclaimer}

Copyright for this article is retained by the author(s), with first publication rights granted to the journal.

This is an open-access article distributed under the terms and conditions of the Creative Commons Attribution license (http://creativecommons.org/licenses/by/3.0/). 